\title{
Engineering Imagination with Ideation
}

\section{Drs. Rebecca Hite, Gail Jones and Jesse S. Jur}

\begin{abstract}
This paper explores the components and efficacy of an engineering-based Research Experience for Teachers (RET) program with a focus on ideation. Leveraging the imaginative and iterative elements of the ideation process, participants engaged in inquiry exploring energy harvesting and novel sensor technology. In modeling the ideation methodology, participants were more engaged in authentic research, which subsequently fostered the creation of novel lesson plans extending beyond the classroom.
\end{abstract}

The importance of research-based, STEMbased RET experiences are a critical feature of bolstering teacher content and pedagogical skills while embedding features of studentcentered elements such as creativity and imagination. During the following school year, participating teachers created an inter-district competition designing Ebolavirus sensors using the One Health framework introduced in the summer research experience program. An example of a student product is provided. A discussion of alignment to science curriculum standards as well as the need of these programs are also discussed.

s science educators prepare for
incorporation of the Next Generation
Science Standards (NGSS) (NGSS, 2013), into K-12 classrooms across the country, engineering education awareness has become widespread. However, full integration of engineering principles into the K-12 curriculum remains a puzzle for science teachers. To replicate engineering practices in industry and academia, students need access to authentic experiences where they engage in the engineering design process to solve real world problems. A fundamental construct within engineering design is ideation, where participants employ constructs of imagination and creativity to design systems or products by overcoming mental roadblocks to address a genuine social need (Hernandez, Shah, \& Smith, 2010). Engaging students through creativity is not only an engaging pedagogical tool for engineering teachers (Scott, 1990) but the process also replicates best practices within the contemporary STEM workplace (Employee engagement strategies in "STEM", 2014).

According to Haik (2003), a curriculum using engineering design must include "development of student creativity, use of open-ended problems, development and use of modern design theory and methodology, formulation of design problem statement and specifications, production processes, concurrent engineering design, and detailed system description" (p.3). This work describes the experiences of 19 middle and high school teachers in a research experience for teachers (RET) summer program to develop 6-12 math and science curricula based upon the brainstorming process of engineering ideation.

This paper describes how a RET experience, rooted in peer collaboration and pedagogical growth, in an authentic engineering environment led to a successful student-driven engineering competition. An example of curriculum developed from this program that employs the ideation process for middle grade science, the One Health sensor competition, is described in detail. 


\section{Addressing the Standards}

The Next Generation Science Standards (NGSS, 2013) include elementary, middle and high school standards that mandate use of engineering design principles. In particular, students are tasked to define criteria and constrains of a design problem, determine criteria and constraints of said problem, develop a model for continual testing and modification, and evaluate competing design solutions.

The intent of these engineering standards was neither to encourage nor discourage the creation of stand-alone engineering courses, as many schools have created new courses in robotics, mechanics, or electronics. The engineering design process, as defined by the NGSS, is an iterative process of defining the problem and developing solutions while optimizing and refining the process (2013).

Figure 1. The Engineering Design Process as Defined by the Next Generation Science Standards.

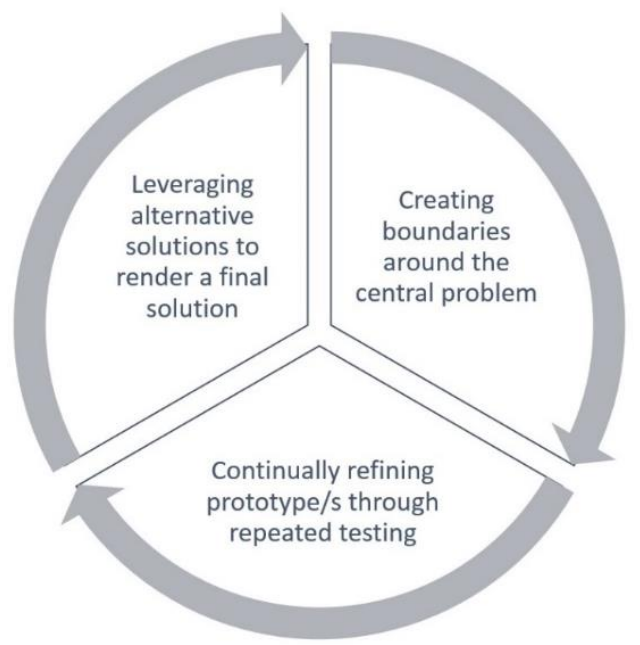

Figure 1. Three pillars of the Engineering Design Process written into the Next Generation Science Standards.

Adapted from APPENDIX I - Engineering Design by Next Generation Science Standards by NGSS Lead States. 2013, Retrieved from http://www.nextgenscience.org/sites/ngss/f iles/Appendix\%201\%20-

$\%$ 20Engineering \%20Design \%20in \%20NG SS\%20-\%20FINAL V2.pdf. Copyright (2013) by Achieve.

An integrated STEM approach is necessary for dealing with the societal problems of today, as Roehrig et al. (2012) argued, which are "multidisciplinary, and many require the integration of multiple STEM concepts to solve them." Integrated STEM education is aligned with the interdisciplinary format of new national standards in English and mathematics (Common Core Standards), as well as in science (Next Generation Science Standards) where engineering and technological design are also infused.

Creativity fostered by the engineering design process is a fundamental component of the Common Core State Standards which stress interdisciplinary learning through the fusion of engineering and technological design (Johnson, 2013). Creativity is also a critical element of understanding the nature of science. According to the National Research Council (NRC, 2012), students "should come to appreciate that science and the current scientific understanding of the world are the result of many hundreds of years of creative human endeavor" (p. 1-2).

According Katehi, Pearson, \& Feder (2009), the "siloed" teaching of STEM has significantly impeded efforts to improve student interest and performance in science and mathematics. They argued that increasing the prominence of engineering education may provide the missing interconnections in STEM teaching and learning vital to holistic understanding. Others have argued that an integrated STEM approach is critical to address the multidisciplinary issues and integrated types of problems students are tasked with in modern society (Roehrig, Moore, Wang, \& Park, 2012). For many teachers this 
new challenge to teach engineering and provide authentic problem solving is daunting.

New forms of professional development that are rooted in the discipline and guided by experts in the field can provide teachers the context and experiences to successfully integrate engineering practices into their classroom. Extant engineering research demonstrates the unique insight gained from team-based work (Donath, Spray, Thompson, Alford, Craig \& Matthews, 2005) and illustrates how participants interact with engineering concepts, which shapes their learning outcomes (Koro-Ljungberg \& Douglas, 2008).

\section{Research Experiences for Teachers}

Research-based experiences can have a significant impact on teachers; a landmark study by Maltese \& Tai (2010) found the presence of authentic, inquiry based science classrooms was one, if not the greatest, factor in student STEM persistence to college graduation. However, without proper induction into or experiences within the STEM profession, science teachers are more likely to rely on memorization of science facts and maintain a hierarchical classroom environment (Dresner \& Worley, 2006).

These conditions negatively contribute to the student perception that science is a passive, boring, codified body of facts; not imagining themselves as active, creatively engaged participants constructing new knowledge or products based in scientific inquiry and engineering design, respectively.

Engaging teachers in engineering design has shown promise as a fruitful way to integrate engineering into the science curriculum; as an RET program focused in engineering may provide "diverse learning opportunities for teachers tailored to their interests and teaching responsibilities" (Ononye, Husting, Jackson, Srinivasan, Sorial, \& Kukreti, 2007, p.3). Based upon research by Pop, Dixon, and Grove (2010), an RET format was chosen to build teacher confidence in developing engineering concepts and practices.

\section{The RET Experience in Ideation}

In the summer of 2014, 19 teachers took part in an in-depth exploration of the engineering design process (ideation) to develop engineering-based solutions to real world problems. The RET program was grounded in the context of human-animal interactions relating to human health concerns and sensors, due to the current research and expertise of the engineers and science educators at the university facilitating the program.

Participants were introduced to the One Health Initiative (One Health), an international consortium of medical health professionals, veterinarians, scientists, and epidemiologists striving to develop preventive strategies in global health by advancing research in public medical education, clinical care, and health monitoring of humans and animals.

One Health pronounces that animal-human interactions are an ongoing, critical and global problem, as more than 70 percent of emerging infections are zoonotic in origin (e.g. insects and mammals) affecting 6 major continents (One Health Initiative, n.d.).

In small groups, teacher-participants were tasked with identifying a geographic region and an area of concern where they would model the ideation within engineering design by devising a sensor system that would minimize or monitor interaction to prevent infectious disease. 
Figure 2.a. Emerging and Reemerging Infections Due to Global Human-Animal Interaction

\section{Emerging and Reemerging infections - $70 \%$ vector-borne or zoonotic}

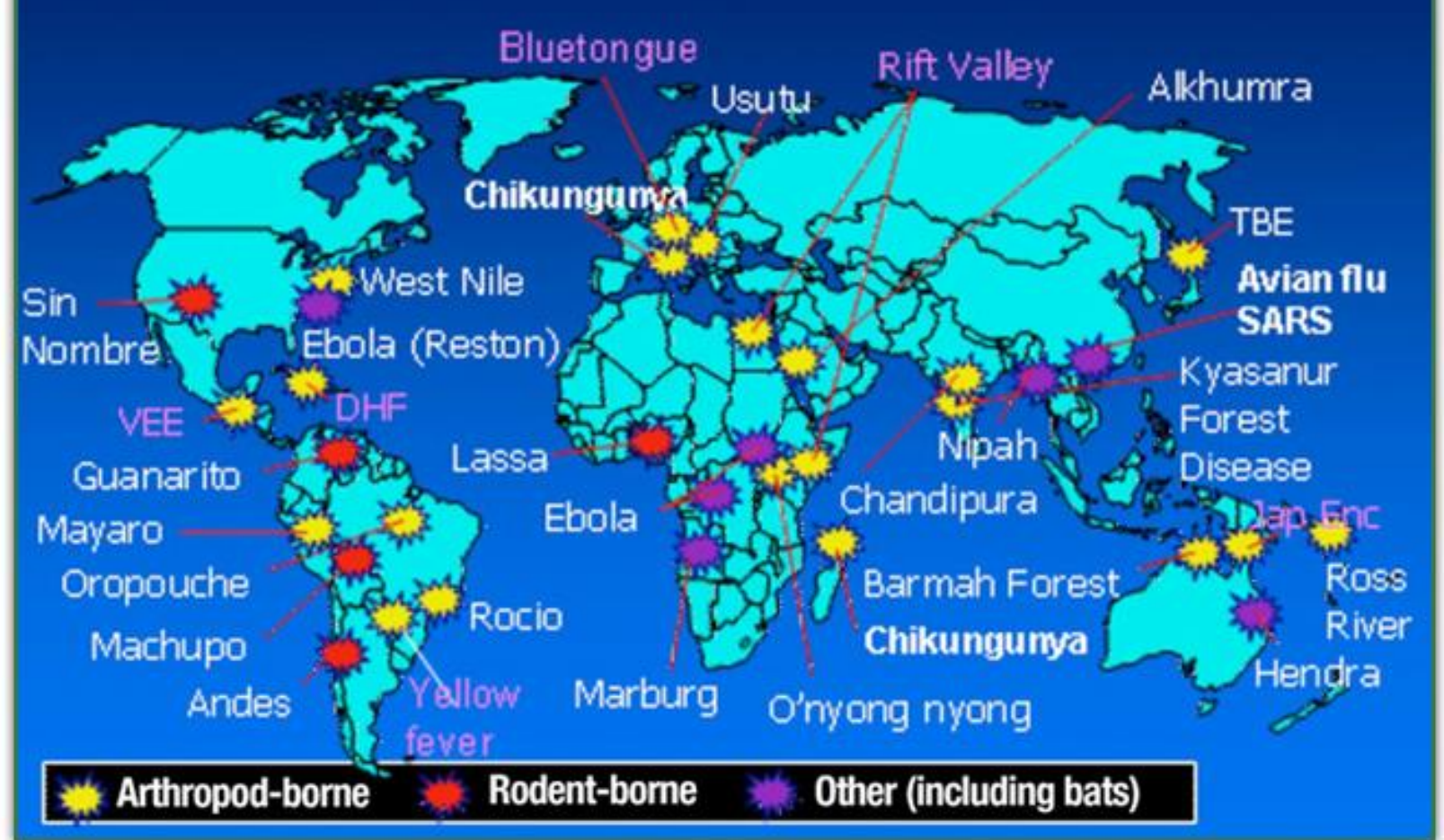

Figure 2.a. A map demonstrating locations of emerging and remerging human infections due to vectorborne and zoonotic disease.

Reprinted from One Health Home Page, by Kahn, L.H., Kaplan, B., Monath, T.P., Woodall, J., \& Conti, L.A. In One Health Initiative, n.d. Retrieved June 1, 2015, from

http://www.onehealthinitiative.com/. Copyright 2015 by One Health. Reprinted with permission. 
Figure 2.b. The One Health Medicine Framework

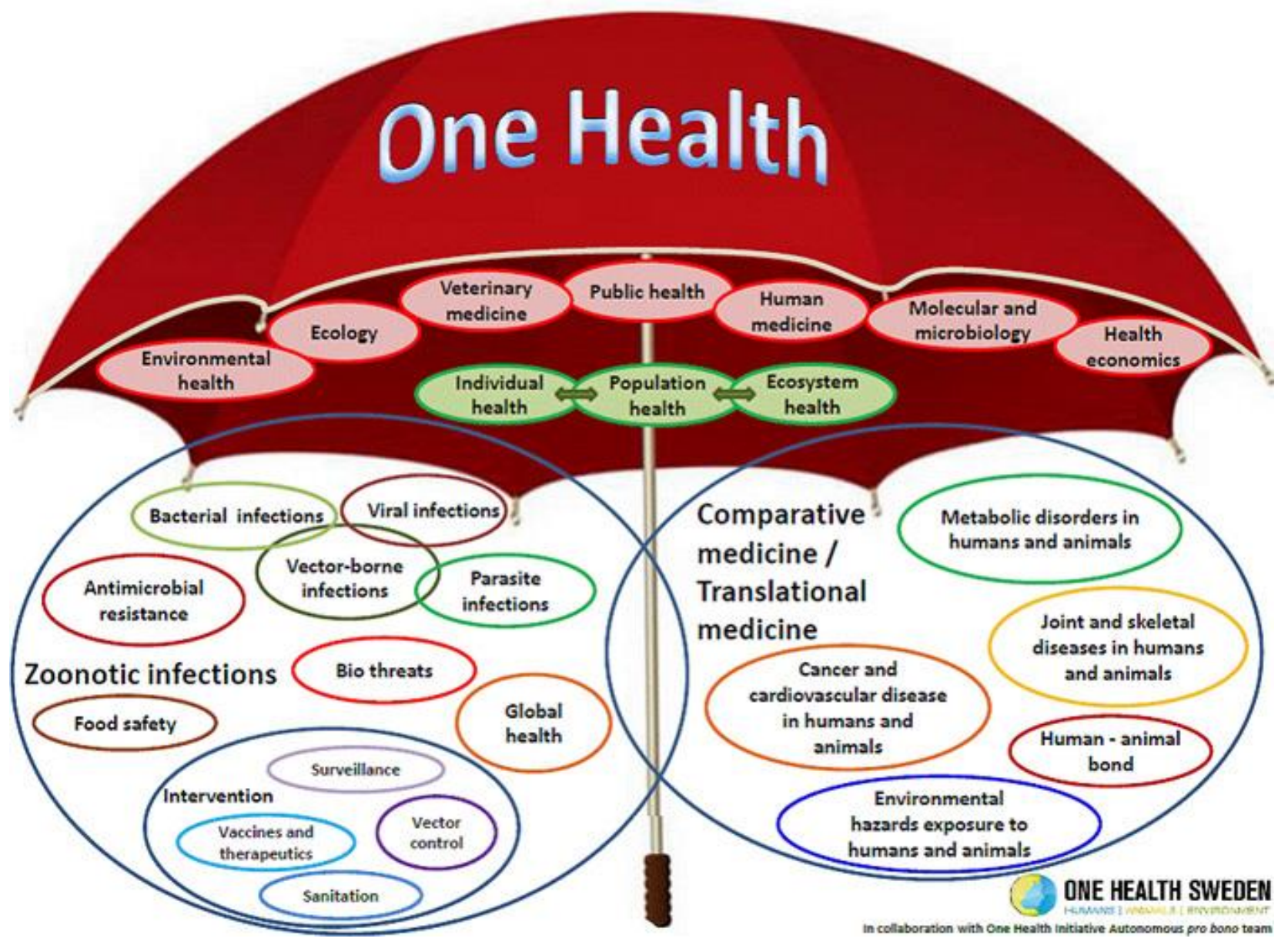

Figure $2 b$. Reorganizing disease and medicine within a global context as it relates to public, environmental, and economic health.

Reprinted from About One Health, by Kahn, L.H., Kaplan, B., Monath, T.P., Woodall, J., \& Conti, L.A. In One Health Initiative, n.d. Retrieved June 1, 2015, from http://www.onehealthinitiative.com/about.php. Copyright 2015 by One Health. Reprinted with permission. 
A part of their professional development process involved learning about current research in engineering practices including novel means of energy harvesting and sensorbased technologies and acquiring the skills of the engineering design process to create a new product. For two months, participants tore down wearable sensors to examine their components, shared in lectures from scholars in the field, conducted product comparisons, and learned to use SolidWorks 3-D printing software to generate their prototypes. They were guided through their professional development by faculty in textile engineering and science education.
Ideation was a key part of the iterative process and engaged teachers in the different stages of product development via collaborative refinement of ideas. Once teachers were provided the content background, they formed groups to identify a common problem from the One Health perspective. Participants determined health challenges such as recognizing dehydration in service animals, measuring the quality of life of free range versus caged chickens in poultry farming, and monitoring Rift Valley fever (RVF) in mainland Africa to prevent outbreaks resulting in epidemics.

Fiqure 3. The Ideation Process Framework

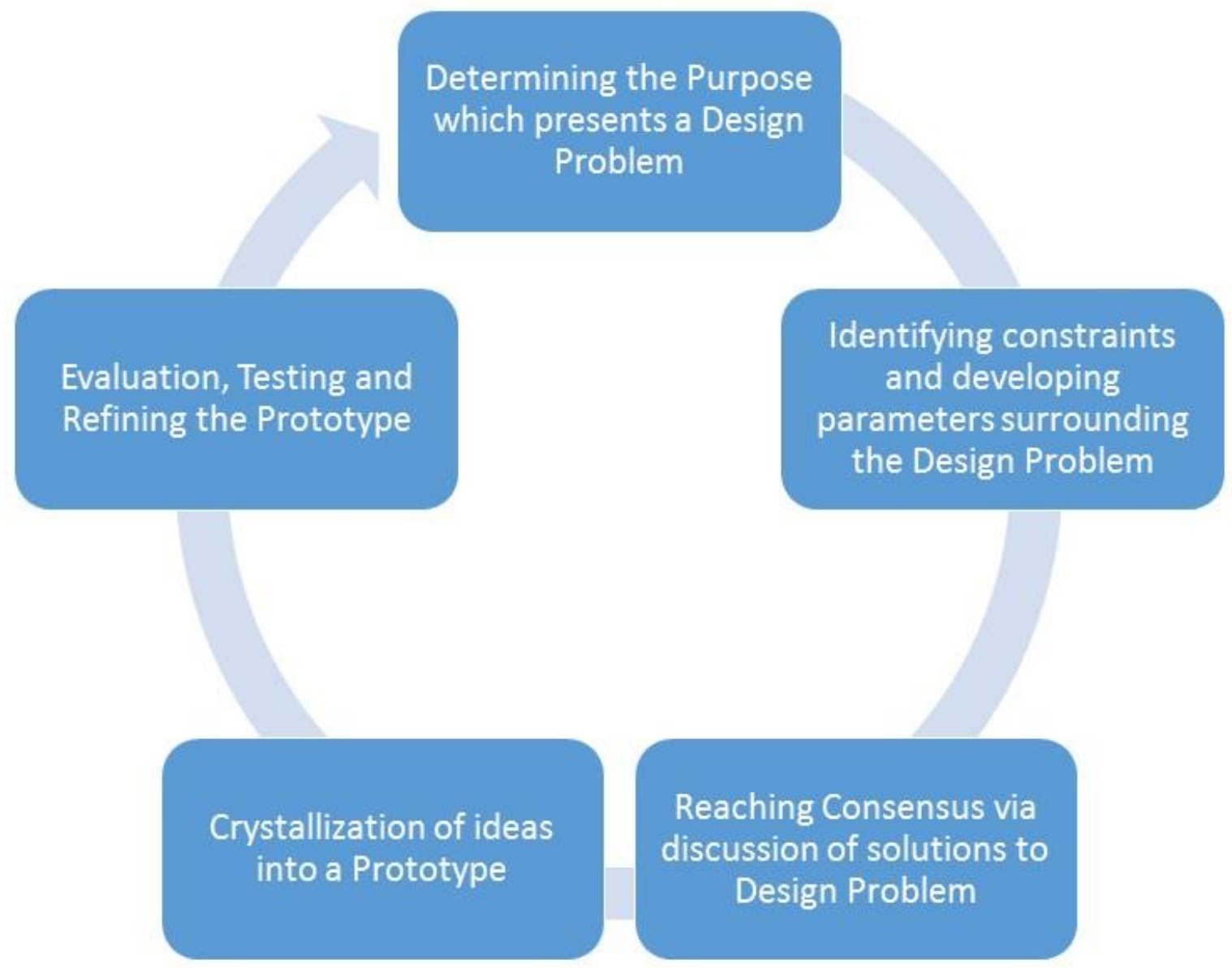

Figure 3. The iterative nature of ideation, a component of the engineering design process.

Adapted from Engineering Design Process, Second Edition by Haik, Y, \& Shahin, T. 2003, Stamford, Connecticut: Cengage Learning. Copyright 2003, 2011 by Cengage Learning. Adapted with permission. 
Using the ideation framework, teams generated specification criteria and design constraints for monitors including but not limited to cost, size, aesthetics, ergonomics, and possible cultural taboos. Participants were encouraged to recommend any plausible idea; all proposals were included and not discarded until there was group discussion and consensus.

During the ideation process, groups outlined their thoughts on white boards to conceptualize and crystallize their product intent and parameters. Design concepts were refined by examination of existing products and reviews of the research literature. Teacher-led groups designed sensor-based products intended to sense hydration levels in search and rescue canines via their sweat, motion detection for chickens as it correlates to physiological effects on poultry health, as well as sensors to detect mosquito movements to trigger interventions to protect people from RVF infection. Participants developed their ideas into collaborative lesson plans addressing mathematics and science standards to be disseminated to teachers throughout the state.

Figure 4.a. The Ideation Process in Action

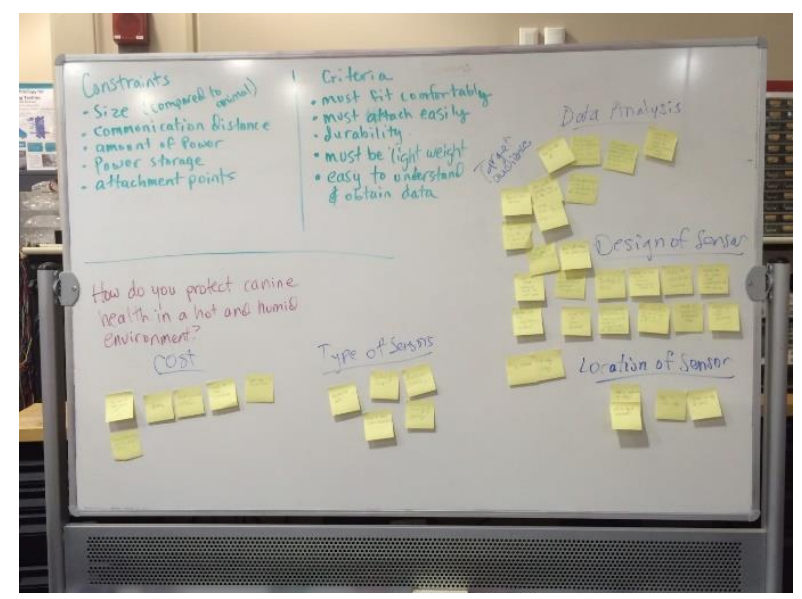

Figure $4 a$. Participating teachers identifying design constraints and parameters guided by the ideation process.

National Science Foundation Nanosystems Engineering Research Center for Advanced Self-powered Systems of Integrated
Sensors and Technologies. Copyright 2014 by ASSIST. Reprinted with permission.

Figure 4.b. Participating Teachers Engaging in the Ideation Process

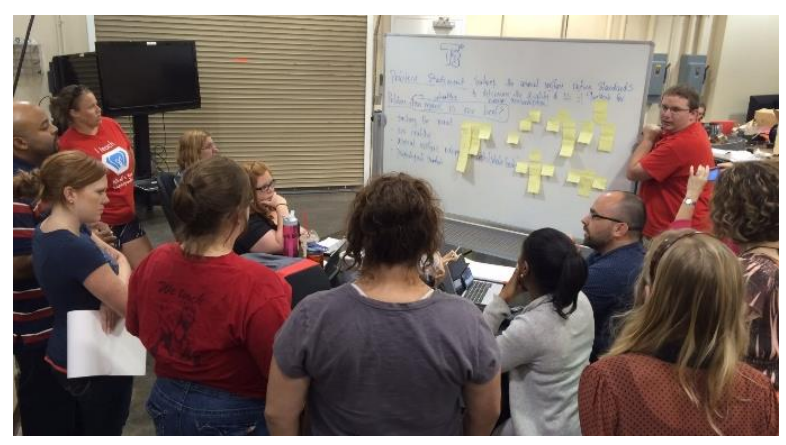

Figure $4 \mathrm{~b}$. Participating teachers reaching consensus and discussing prototyping guided by the ideation process.

National Science Foundation Nanosystems Engineering Research Center for Advanced Self-powered Systems of Integrated Sensors and Technologies. Copyright 2014 by ASSIST. Reprinted with permission.

\section{Translating the RET Program to Fostering Ideation in the Classroom}

Following the RET program, teachers replicated the ideation process with their students using the curriculum they developed that summer. The following is an example from a teacher, working with the RET facilitators, who developed an inter-district student competition to design a sensor to detect Ebola in the most heavily impacted countries of Western Africa from the 2014 epidemic. This topic was of particular interest since at the height of the outbreak, an estimated 21,000 individuals were affected with the disease and new cases doubled every 20 days (CDC, 2015).

Using information and experience from the RET, the teacher scaffolded the ideation process for student teams to design their sensors. Students were tasked with researching epidemiological information regarding signs, symptoms and methods of transmitting Ebolavirus. Student groups were encouraged to use credible online resources to compile information about the disease and discuss best practices of current sensor 
technology to detect and communicate possible infection to the individual and local health care workers. Each device had to utilize a novel form of energy harvesting and storage, not relying on costly and bulky battery power, derived from the human body. During their research, students were introduced to the concepts of thermoelectrics, piezoelectrics, and supercapacitors. Once student teams decided on the sensor's modality and energy source, they needed to further consider cultural factors and economic impact to encourage its widespread use and ease of construction, upkeep and wear. Using concepts from the NGSS (2013), student teams revised prototypes through testing, consultation with engineers, and discussion in their team meetings.
Student products were evaluated on the criteria of feasibility, aesthetics, wearability and accurately sourced materials and judged on the following rubric. In addition to prototypes, students created an awareness-based advertising campaign to communicate and promote the importance of their sensor system. This additional task is significant as it infuses a largely underrepresented aspect of the nature of science and the NGSS (2013), which not only mandates communication with the public regarding scientific discovery but is also a fundamental aspect of creating scientific knowledge (Nielsen, 2012).

Figure 5. Teacher or Evaluator Scoring Rubric for One Health Sensor Project

\title{
One Health Sensor Judging and/or Scoring Rubric
}

\author{
Note: A score point of 0 is only awarded if the element is missing.
}

\begin{tabular}{|c|c|c|c|c|}
\hline $\begin{array}{c}\text { Product } \\
\text { Aspect }\end{array}$ & Description & Highly Proficient & Proficient & $\begin{array}{l}\text { Developing } \\
\text { Proficiency }\end{array}$ \\
\hline Feasibility & $\begin{array}{l}\text { The product designed would } \\
\text { work well... } \\
\text { - } \quad \text { in the chosen } \\
\text { environment. } \\
\text { as a sensor on a } \\
\text { wearable device. } \\
\text { data is transmitted (if } \\
\text { necessary) in a manner } \\
\text { conducive to the } \\
\text { technological needs, } \\
\text { existing infrastructure, } \\
\text { and surroundings. }\end{array}$ & $\begin{array}{l}\text { Contains exemplary } \\
\text { work within the } \\
\text { category. } \\
\text { Meets } 3 \text { or more } \\
\text { bulleted points } \\
\text { well. }\end{array}$ & $\begin{array}{l}\text { Contains good or } \\
\text { average work } \\
\text { within the } \\
\text { category. } \\
\text { Meets } 1 \text { to } 3 \\
\text { bulleted points } \\
\text { well. }\end{array}$ & $\begin{array}{l}\text { Contains below } \\
\text { average work } \\
\text { within the } \\
\text { category. } \\
\text { Meets none of the } \\
\text { bulleted points } \\
\text { well. }\end{array}$ \\
\hline Wearability & $\begin{array}{l}\text { The product designed would be } \\
\text { able to... } \\
\text { - } \\
\text { withstand the } \\
\text { movements, } \\
\text { temperatures, and } \\
\text { fluids found in the } \\
\text { environment it is } \\
\text { placed in. } \\
\text { be made out of a } \\
\text { material that is the } \\
\text { least obtrusive for the } \\
\text { highest percentage of } \\
\text { people (i.e. it is not } \\
\text { made out of a material } \\
\text { that has many known } \\
\text { allergens). }\end{array}$ & $\begin{array}{l}\text { Contains exemplary } \\
\text { work within the } \\
\text { category. } \\
\text { Meets } 3 \text { or more } \\
\text { bulleted points } \\
\text { well. }\end{array}$ & $\begin{array}{l}\text { Contains good or } \\
\text { average work } \\
\text { within the } \\
\text { category. } \\
\text { Meets } 1 \text { to } 3 \\
\text { bulleted points } \\
\text { well. }\end{array}$ & $\begin{array}{l}\text { Contains below } \\
\text { average work } \\
\text { within the } \\
\text { category. } \\
\text { Meets none of the } \\
\text { bulleted points } \\
\text { well. }\end{array}$ \\
\hline
\end{tabular}




\begin{tabular}{|c|c|c|c|c|}
\hline & $\begin{array}{l}\text { generally } \\
\text { comfortable } \\
\text { and not too } \\
\text { bulky to wear. }\end{array}$ & & & \\
\hline Aesthetics & $\begin{array}{l}\text { The product designed } \\
\text { would keep in mind... } \\
\text { cultural } \\
\text { sensitivity of } \\
\text { the area in } \\
\text { which the } \\
\text { design will be } \\
\text { distributed } \\
\text { (e.g. if the } \\
\text { color red is } \\
\text { taboo in your } \\
\text { region you will } \\
\text { not design a } \\
\text { product with } \\
\text { red as the } \\
\text { primary color). } \\
\text { stylish } \\
\text { considerations } \\
\text { including } \\
\text { whether or } \\
\text { not it is } \\
\text { visually } \\
\text { appealing. } \\
\text { designs that } \\
\text { reflect the } \\
\text { target age and } \\
\text { gender group } \\
\text { OR towards } \\
\text { neutrality (e.g. } \\
\text { bright colors } \\
\text { for children, } \\
\text { one-size-fits- } \\
\text { all sizes, etc.) } \\
\end{array}$ & $\begin{array}{l}\text { Contains } \\
\text { exemplary work } \\
\text { within the } \\
\text { category. } \\
\text { Meets } 3 \text { or more } \\
\text { bulleted points } \\
\text { well. }\end{array}$ & $\begin{array}{l}\text { Contains good or } \\
\text { average work } \\
\text { within the } \\
\text { category. } \\
\text { Meets } 1 \text { to } 3 \\
\text { bulleted points } \\
\text { well. }\end{array}$ & $\begin{array}{l}\text { Contains below } \\
\text { average work within } \\
\text { the category. } \\
\text { Meets none of the } \\
\text { bulleted points well. }\end{array}$ \\
\hline Sensor placement & $\begin{array}{l}\text { The product designed } \\
\text { would consider... } \\
\text { - } \\
\text { Body } \\
\text { location/s that } \\
\text { would collect } \\
\text { and transmit } \\
\text { the most data } \\
\text { (i.e. a } \\
\text { hydration } \\
\text { sensor would } \\
\text { be placed on } \\
\text { the inner } \\
\text { arm). } \\
\text { Body } \\
\text { location/s that } \\
\text { maximize } \\
\text { comfort and } \\
\text { minimize } \\
\text { discomfort for } \\
\text { the wearer. }\end{array}$ & $\begin{array}{l}\text { Contains } \\
\text { exemplary work } \\
\text { within the } \\
\text { category. } \\
\text { Meets } 3 \text { or more } \\
\text { bulleted points } \\
\text { well. }\end{array}$ & $\begin{array}{l}\text { Contains good or } \\
\text { average work } \\
\text { within the } \\
\text { category. } \\
\text { Meets } 1 \text { to } 3 \\
\text { bulleted points } \\
\text { well. }\end{array}$ & $\begin{array}{l}\text { Contains below } \\
\text { average work within } \\
\text { the category. } \\
\text { Meets none of the } \\
\text { bulleted points well. }\end{array}$ \\
\hline
\end{tabular}




\begin{tabular}{|c|c|c|c|c|}
\hline & $\begin{array}{ll}\text { Body } \\
\text { location/s that } \\
\text { are minimally } \\
\text { invasive } \\
\text { unless } \\
\text { designed } \\
\text { specifically for } \\
\text { that location } \\
\text { (e.g. a sensor } \\
\text { in teeth). }\end{array}$ & & & \\
\hline Power & $\begin{array}{l}\text { The product designed } \\
\text { would be powered } \\
\text { by... } \\
\text { - } \quad \text { an appropriate } \\
\text { type of power } \\
\text { (i.e. plutonium } \\
\text { for a wearable } \\
\text { sensor is too } \\
\text { powerful and } \\
\text { unsafe). } \\
\text { ubiquitous } \\
\text { sources easily } \\
\text { sourced in the } \\
\text { selected } \\
\text { location or } \\
\text { desired } \\
\text { market. } \\
\text { a method that } \\
\text { provides a } \\
\text { lengthy } \\
\text { lifespan for } \\
\text { the product. } \\
\text { a type of } \\
\text { power that is } \\
\text { preferably } \\
\text { renewable. }\end{array}$ & $\begin{array}{l}\text { Contains } \\
\text { exemplary work } \\
\text { within the } \\
\text { category. } \\
\text { Meets } 3 \text { or more } \\
\text { bulleted points } \\
\text { well. }\end{array}$ & $\begin{array}{l}\text { Contains good or } \\
\text { average work } \\
\text { within the } \\
\text { category. } \\
\text { Meets } 1 \text { to } 3 \\
\text { bulleted points } \\
\text { well. }\end{array}$ & $\begin{array}{l}\text { Contains below } \\
\text { average work within } \\
\text { the category. } \\
\text { Meets none of the } \\
\text { bulleted points well. }\end{array}$ \\
\hline Ad Campaign & Description & Highly Proficient & Proficient & $\begin{array}{l}\text { Developing } \\
\text { Proficiency }\end{array}$ \\
\hline Instructions & $\begin{array}{l}\text { The advertising } \\
\text { campaign should } \\
\text { contain instructions } \\
\text { that are... } \\
\text { - } \quad \text { concise on } \\
\text { how to use } \\
\text { your device. } \\
\text { - } \text { written for } \\
\text { the targeted } \\
\text { audiences } \\
\text { (consider } \\
\text { literacy levels } \\
\text { or age } \\
\text { appropriate } \\
\text { words and } \\
\text { language.) } \\
\text { graphics and } \\
\text { designs that } \\
\text { aid the user in } \\
\text { understanding } \\
\text { how to use } \\
\text { and maintain } \\
\text { the product. }\end{array}$ & $\begin{array}{l}\text { Contains } \\
\text { exemplary work } \\
\text { within the } \\
\text { category. } \\
\text { Meets } 3 \text { or more } \\
\text { bulleted points } \\
\text { well. }\end{array}$ & $\begin{array}{l}\text { Contains good or } \\
\text { average work } \\
\text { within the } \\
\text { category. } \\
\text { Meets } 1 \text { to } 3 \\
\text { bulleted points } \\
\text { well. }\end{array}$ & $\begin{array}{l}\text { Contains below } \\
\text { average work within } \\
\text { the category. } \\
\text { Meets none of the } \\
\text { bulleted points well. }\end{array}$ \\
\hline
\end{tabular}




\begin{tabular}{|c|c|c|c|c|}
\hline Awareness & $\begin{array}{l}\text { The advertising campaign } \\
\text { should contain... } \\
\text { - } \quad \text { specific } \\
\text { information about } \\
\text { the spread of } \\
\text { Ebola, how to } \\
\text { prevent } \\
\text { transmission, and } \\
\text { how your product } \\
\text { will help protect } \\
\text { against/prevent/or } \\
\text { provide early } \\
\text { detection of } \\
\text { Ebola. } \\
\text { information from } \\
\text { vetted and } \\
\text { reputable sources } \\
\text { (CDC, WHO, } \\
\text { University-based } \\
\text { research or } \\
\text { journal articles). } \\
\text { a call to action } \\
\text { that empowers } \\
\text { the user in social } \\
\text { responsibility and } \\
\text { educating others. }\end{array}$ & $\begin{array}{l}\text { Contains } \\
\text { exemplary work } \\
\text { within the } \\
\text { category. } \\
\text { Meets } 3 \text { or more } \\
\text { bulleted points } \\
\text { well. }\end{array}$ & $\begin{array}{l}\text { Contains good or } \\
\text { average work } \\
\text { within the } \\
\text { category. } \\
\text { Meets } 1 \text { to } 3 \\
\text { bulleted points } \\
\text { well. }\end{array}$ & $\begin{array}{l}\text { Contains below } \\
\text { average work within } \\
\text { the category. } \\
\text { Meets none of the } \\
\text { bulleted points well. }\end{array}$ \\
\hline Feasibility & $\begin{array}{l}\text { The advertising campaign } \\
\text { should consider... } \\
\text { - } \quad \text { advertising rules } \\
\text { and laws for this } \\
\text { specific } \\
\text { geographic } \\
\text { location e.g. } \\
\text { flyers may be } \\
\text { appropriate to } \\
\text { reach the target } \\
\text { audience/user } \\
\text { e.g. if you have a } \\
\text { radio ad make } \\
\text { sure it is in a } \\
\text { location where a } \\
\text { large percentage } \\
\text { of the population } \\
\text { in the area has } \\
\text { access to a radio, } \\
\text { if it is a } \\
\text { billboard/poster } \\
\text { make sure it is } \\
\text { written to on the } \\
\text { level of the } \\
\text { average literacy } \\
\text { level for the area). } \\
\text { advertising that is } \\
\text { ecologically } \\
\text { friendly. }\end{array}$ & $\begin{array}{l}\text { Contains } \\
\text { exemplary work } \\
\text { within the } \\
\text { category. } \\
\text { Meets } 3 \text { or more } \\
\text { bulleted points } \\
\text { well. }\end{array}$ & $\begin{array}{l}\text { Contains good or } \\
\text { average work } \\
\text { within the } \\
\text { category. } \\
\text { Meets } 1 \text { to } 3 \\
\text { bulleted points } \\
\text { well. }\end{array}$ & $\begin{array}{l}\text { Contains below } \\
\text { average work within } \\
\text { the category. } \\
\text { Meets none of the } \\
\text { bulleted points well. }\end{array}$ \\
\hline
\end{tabular}




\begin{tabular}{|c|c|c|c|c|}
\hline & 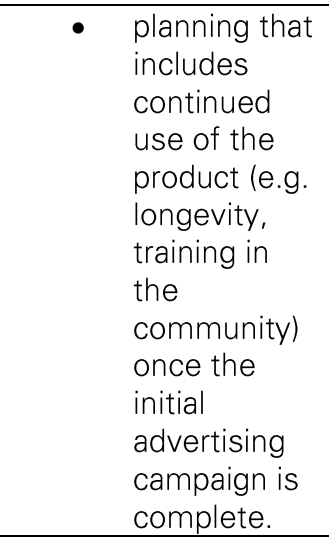 & & & \\
\hline Group Dynamics & Description & Highly Proficient & Proficient & $\begin{array}{l}\text { Developing } \\
\text { Proficiency }\end{array}$ \\
\hline Planning & $\begin{array}{c}\text { The product team } \\
\text { should contain... } \\
\text { - } \quad \text { a clear } \\
\text { product } \\
\text { planning } \\
\text { design } \\
\text { outline. } \\
\text { - a clear } \\
\text { advertising } \\
\text { campaign } \\
\text { plan. } \\
\text { documented } \\
\text { opportunities } \\
\text { where group } \\
\text { members } \\
\text { conducted } \\
\text { background } \\
\text { research } \\
\text { (e.g. online, } \\
\text { journals, } \\
\text { asking } \\
\text { engineers, } \\
\text { etc.) }\end{array}$ & $\begin{array}{l}\text { Contains } \\
\text { exemplary work } \\
\text { within the } \\
\text { category. } \\
\text { Meets } 3 \text { or more } \\
\text { bulleted points } \\
\text { well. }\end{array}$ & $\begin{array}{l}\text { Contains good or } \\
\text { average work } \\
\text { within the } \\
\text { category. } \\
\text { Meets } 1 \text { to } 3 \\
\text { bulleted points } \\
\text { well. }\end{array}$ & $\begin{array}{l}\text { Contains below } \\
\text { average work within } \\
\text { the category. } \\
\text { Meets none of the } \\
\text { bulleted points well. }\end{array}$ \\
\hline Collaboration & $\begin{array}{l}\text { The product team } \\
\text { should contain... } \\
\text { - clear } \\
\text { evidence of } \\
\text { a group } \\
\text { effort where } \\
\text { each } \\
\text { individual } \\
\text { was } \\
\text { engaged in } \\
\text { the planning } \\
\text { and } \\
\text { production } \\
\text { of the } \\
\text { product and } \\
\text { advertising } \\
\text { campaign. }\end{array}$ & $\begin{array}{l}\text { Contains } \\
\text { exemplary work } \\
\text { within the } \\
\text { category. } \\
\text { Meets } 3 \text { or more } \\
\text { bulleted points } \\
\text { well. }\end{array}$ & $\begin{array}{l}\text { Contains good or } \\
\text { average work } \\
\text { within the } \\
\text { category. } \\
\text { Meets } 1 \text { to } 3 \\
\text { bulleted points } \\
\text { well. }\end{array}$ & $\begin{array}{l}\text { Contains below } \\
\text { average work within } \\
\text { the category. } \\
\text { Meets none of the } \\
\text { bulleted points well. }\end{array}$ \\
\hline
\end{tabular}




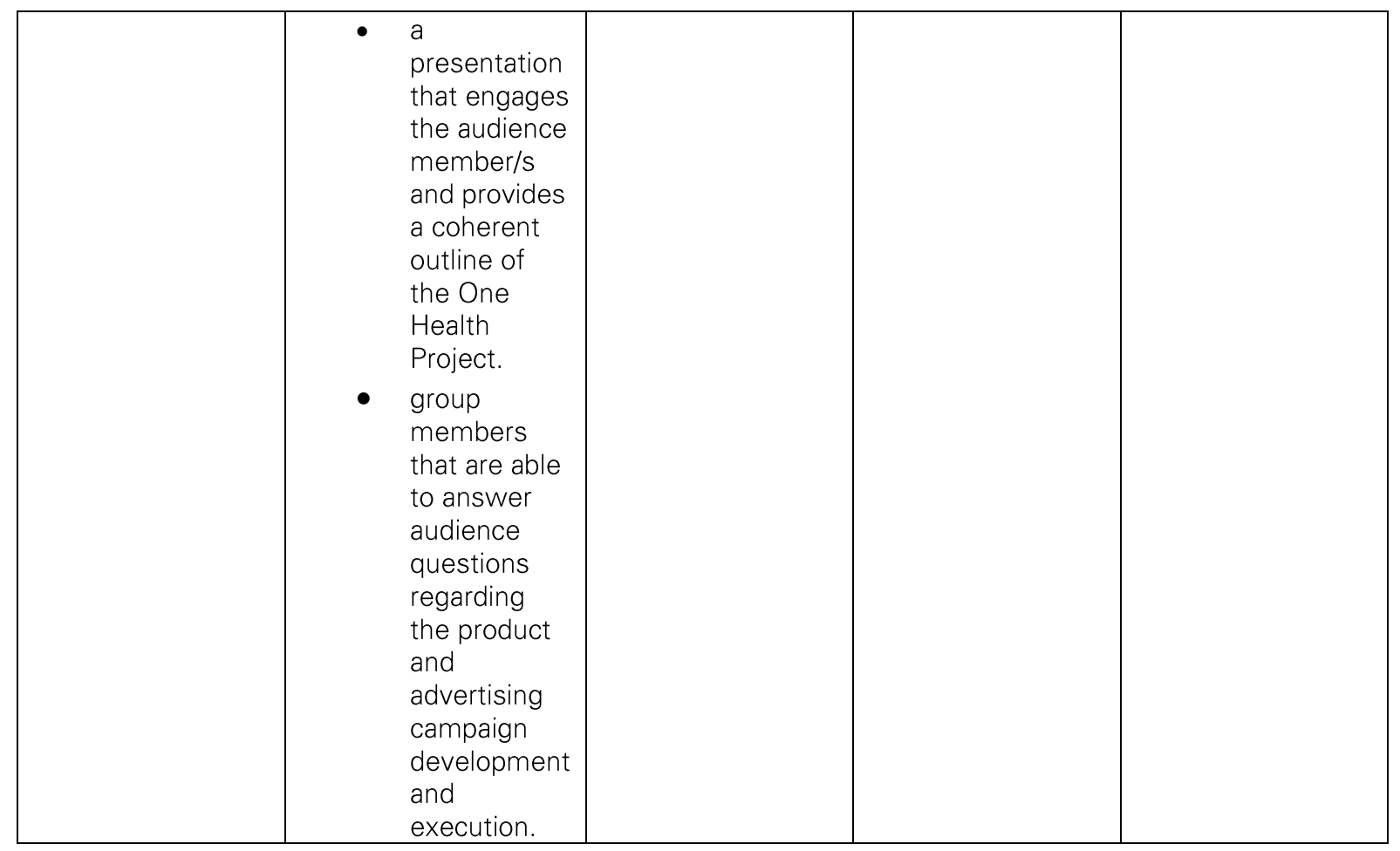

Figure 5. Scoring rubric for student ideation projects using the One Health concepts of preventing global health threats.

By Hite, R., 2015. Reprinted with permission.

Team submissions included designs for detecting the virus through non-invasive sources of specimens and the body's natural nonspecific immunity reaction. One student project that is highlighted in this paper exemplifies the process of engineering ideation. This group designed a wristband specifically for use in Liberia, a heavily impacted area from the Ebolavirus epidemic.

They decided that their device would be powered by human body heat and solar power, energy sources that are constant and abundant. Using locally sourced hemp and nylon for adjustable sizing, sensor cost and manufacturing would be minimal out of respect for the economically depressed region.

Consisting of a LCD screen and manual touch buttons, users would be educated about the signs and symptoms of the disease and then quizzed regarding their current health status.
If their responses indicated probable infection, a GPS locator would direct them to the closest medical facility for treatment. Through their cultural research, this team found the Liberian flag had roots in slavery, so they decided instead on a culturally accepted and relevant pan-African color scheme.

Using the rubric provided, this group earned highly proficient status in the categories of feasibility, wearability and aesthetics due to their acknowledgment of technological limitations of the area, astute use of available materials and awareness of cultural issues, respectively.

It is evident this project submission reflects the collaborative process and critical thinking essential to the ideation process and the defining of boundaries and revising of prototypes recommended by the NGSS (2013). 
Figure 6. Student work of an Ebolavirus Sensor

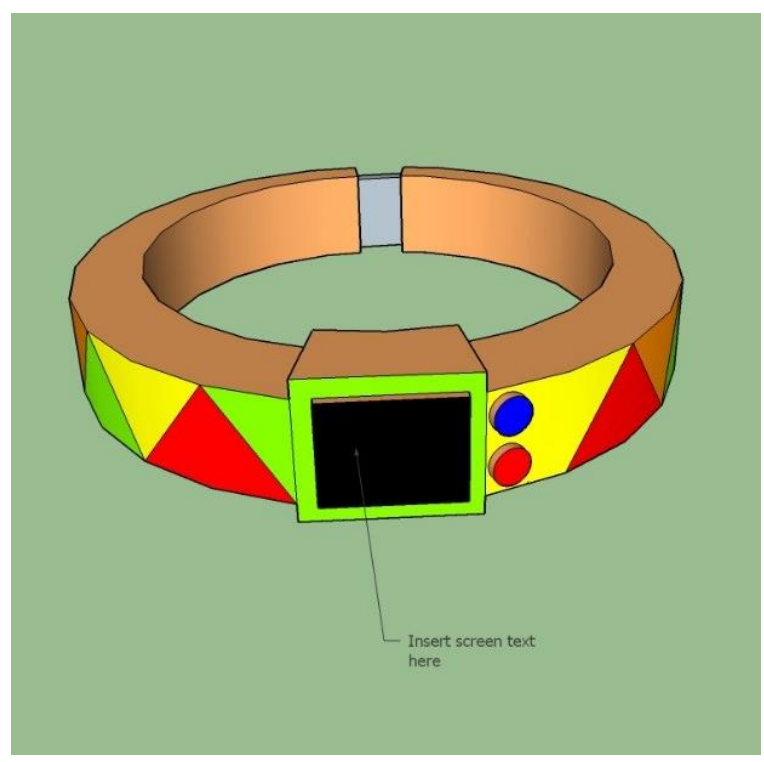

Figure 6. Student work demonstrating the concepts of feasibility, wearability, aesthetics, and sensor placement.

By Maxwell H., 2015. Reprinted with permission.

\section{Conclusion}

By participating in their own projects where the ideation process was modeled by engineers in an extended professional development environment (e.g. RET program), this student project provides evidence that a teacher participant was able to construct their own knowledge from the RET experience and develop a vision about how ideation may be used in the classroom (Pop, Dixon, \& Grove, 2010). Ideation is a viable classroom tool to engage all students in the engineering design process. Students with different strengths, whether it was technical skills, trend awareness, or sensitivity to ethnical issues, students can all positively contribute to the ideation process (Schweitzer, Gassmann, \& Rau, 2014). Cultivation of this type of classroom science environment is particularly important in developing a STEM identity, efficacy, and persistence: critically important in reinforcing the STEM pipeline for under-represented populations including Black, Hispanic (Andersen \& Ward, 2013) and female (Hazari, Tai \& Sadler, 2007) students. This paper suggests use of RET programs may be a vital component in the ecosystem of teacher professional development to provide educators with the preparation and scaffolding to explore in-depth engineering practices, like ideation. Based upon this teacher-developed project, this paper demonstrates that engineering concepts and ideation may be successfully replicated within middle and high school classrooms, providing a powerful opportunity to embed engineering and critical thinking skills into current science and mathematics courses.

\section{Acknowledgements}

The authors would like to acknowledge the teachers who spent their summer conducting engineering research at North Carolina State University. This program was supported by the National Science Foundation's Award \# 1407202 on Wearable Nanodevices, Linking Health and Environment: RET in Engineering and Computer Science Site.

\section{References}

Andersen, L., \& Ward, T.J. (2013). ExpectancyValue Models for the STEM Persistence Plans of Ninth-Grade, High-Ability Students: A Comparison between Black, Hispanic, and White Students. Science Education, n/a-n/a. doi: 10.1002/sce. 21092

Centers for Disease Control and Prevention (CDC). (2015). Ebola (Ebola Virus Disease). Retrieved from http://www.cdc.gov/vhf/ebola/

Donath, L., Spray, R., Thompson, N.S., Alford, E.M., Craig, N., \& Matthews, M.A. (2005). Characterizing discourse among undergraduate researchers in an inquiry-based community of practice. Journal of Engineering Education, 94, 403-417.

Dresner, M., \& Worley E. (2006). Teacher Research Experiences, Partnerships with Scientists, and Teacher Networks Sustaining Factors from Professional Development. Journal of Science Teacher Education 17(1), 114. doi: 10.1007/s10972-005-9000-5 
Emerging and Reemerging Infections [Image]. (n.d.). Retrieved from: http://www.onehealthinitiative.com/

Employee engagement strategies in 'STEM' workplaces spark creativity. (2014). PR News, 70(1) Retrieved from

http://search.proquest.com/docview/149097220 8? accountid $=12725$

Engineering Design in the NGSS. [Image]. (2013). Retrieved from http://www.nextgenscience.org/sites/ngss/files/ Appendix \%201\%20$\% 20$ Engineering $\% 20$ Design $\% 20$ in $\% 20$ NGSS $\%$ 20-\%20FINAL V2.pdf

Haik, Y. (2003). Engineering Design Process. South Melbourne, Victoria, Australia: Thomson/Brooks/Cole.

Haik, Y \& Shahin, T. (Authors). (2003). Ideation Process. [Image]. Stamford, Connecticut: Cengage Learning.

Hazari, Z., Tai, R.H., \& Sadler, P.M. (2007). Gender differences in introductory university physics performance: The influence of high school physics preparation and affective factors. Science Education, 91(6), 847-876.

Hernandez, N.V., Shah, J.J., \& Smith, S.M. (2010). Understanding design ideation mechanisms through multilevel aligned empirical studies. Design Studies, 31(4), 382410.

Hite, R. (Author). (2015). One Health Sensor Judging and/or Scoring Rubric. [Image].

Johnson, C.C. (2013). Conceptualizing Integrated STEM Education. School Science and Mathematics, 113(8), $367-368$.

Katehi, L., Pearson, G., \& Feder, M. (2009). The Status and Nature of K-12 Engineering Education in the United States. The National Academy of Engineering. Retrieved from https://www.nae.edu/File.aspx?id=16147

Koro-Ljungberg, M., \& Douglas, E.P. (2008). State of Qualitative research in Engineering
Education: Meta-Analysis of JEE Articles, 20052006. Journal of Engineering Education, 97(2), 163-175.

Maltese, A. \& Tai, R. (2010). Pipeline

Persistence: Examining the Association of Educational Experiences with Earned Degrees in STEM among U.S. Students. Science Education, 95(5), 877-907. doi: $10.1002 /$ sce. 20441

Maxwell, H. (Photographer). (2015). Student work of an Ebolavirus Sensor. [Photograph].

Nanosystems Engineering Research Center for Advanced Self-powered systems of integrated sensors and technologies. (Photographer). (2014). Participating Teachers Engaging in the Ideation Process. [Photograph].

Nanosystems Engineering Research Center for Advanced Self-powered systems of integrated sensors and technologies. (Photographer). (2014). The Ideation Process in Action. [Photograph].

National Resource Council (NRC). 2012. A framework for K-12 science education: Practices, crosscutting concepts, and core ideas. Washington, DC: National Academics Press.

Next Generation Science Standards (NGSS). (2013). APPENDIX I - Engineering Design in the NGSS. Retrieved from http://www.nextgenscience.org/sites/ngss/files/ Appendix\%201\%20$\% 20$ Engineering $\% 20$ Design $\% 20$ in $\% 20$ NGSS $\%$ 20-\%20FINAL_V2.pdf

Nielsen, K.H. (2012). Scientific Communication and the Nature of Science. Science \& Education, 22(9), 2067-2086.

One Health Initiative. (n.d.). About One Health. Retrieved from http://www.onehealthinitiative.com/index.php

One Health Sweden [Image]. (n.d.). Retrieved from:

http://www.onehealthinitiative.com/about.php 
Ononye, G., Husting, C., Jackson, E., Srinivasan, R., Sorial, G., \& Kukreti, A. (2007). Research

Experience for Teachers (RET): The Art of Formal Education. Journal of Environmental Engineering, 133(1), 2-3.

Pop, M. M., Dixon, P., \& Grove, C. M. (2010). Research Experiences for Teachers (RET): Motivation, Expectations, and Changes to Teaching Practices due to Professional Program Involvement. Journal of Science Teacher Education, 21(2), 127-147.

Roehrig, G.H., Moore, T.J., Wang, H.H., \& Park, M.S. (2012). Is adding the E enough?

Investigating the impact of K-12 engineering standards on the implantation of STEM integration. School Science and Mathematics, 112(1), 31-44.

Schweitzer, F., Gassmann, O., \& Rau, C. (2014). Lessons from Ideation: Where Does User Involvement Lead Us? Creativity and Innovation Management, 23(2) 155-167.

Scott, R. (1990). Stimulating Students' Design Creativity, Journal of Engineering Design, 1(3), 279-288.

\section{About the Authors}

Rebecca Hite, a 2008-2010 Kenan Fellow, is an Assistant Professor of STEM Education at Texas Tech University.

Gail Jones is an Alumni Distinguished Graduate Professor in the College of Education at NC State University.

Jesse S. Jur is an Assistant Professor in the College of Textiles at NC State University. 